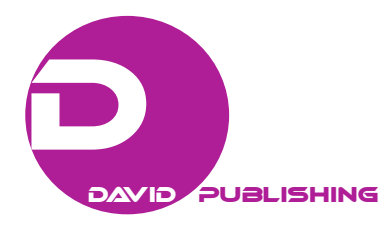

\title{
Lesson Study Makes Teachers Learn
}

\author{
Hendra Darmawan \\ Ahmad Dahlan University, Yogyakarta, Indonesia
}

\begin{abstract}
Being professional teacher is a process of acting and self empowering of teachers collectively and continuously. A teacher is not merely transferring knowledges and subject matters to the students but also internalizing the values; professionalism, knowledge laedership, community empowerment, etc. Partnership, professional development, and learning community are possibly gained by the teachers through lesson study implementasion interconnectedly and mutually. This paper aims at elaborating on the experience of State Junior High School 1 Srandakan Bantul Yogyakarta in implementing lesson study as a break-through to enhance the teachers' professional development incorporating the three mechanisms of lesson study. This school has conducted lesson study for about three years. The study resulted that 80 percent of teachers achieve their competence in planning, doing, and reflecting the lesson through observing other teachers performance and being observed interchangeably.
\end{abstract}

Keywords: lesson study, teachers, learning

\section{Introduction}

Education is an effort to help students improving their potency. Based on "Undang-Undang No. 20 Tahun 2003 tentang Sistem Pendidikan Nasional”, education is a systematic effort to create an effective teaching and learning process so that the students are able to improve their potency and achieve the power of spiritual, self control, good personality, character, and skill. To cover those students' improvements, teacher should also improve their competencies to gain an effective teaching learning process.

Moreover, teacher should understand the way they teach and the way the students learn. The starting point in understanding the teachers' way on teaching is about what teaching is. Teaching is the arrangement of information (method, media, and equipment) and environment to facilitate learning. This arrangement is the responsibility of instructor (Heinich, Molenda, Russell, Sharon, 1996, p. 8). Based on the statement above, teacher becomes the main factor in achieving the goal of education. Consequently, teachers competency become the absolute factor and basic requirement in achieving those goals.

Lesson study is one of the efforts to improve education system quality focusing on teacher aspect. Lesson study gives many chances for teachers to develop their competencies and provides the opportinity to discuss the content that they are going to teach and refine their understanding of the content. Lesson study also gives chances for teacher to learn a great deal about how students learn and think new things.

State Junior High School (Sekolah Menengah Pertama Negeri-SMPN) 1 Srandakan is one of schools that apply lesson study. On December 2007, SMPN 1 Srandakan was piloted as one of the pilot schools of "Lesson 
Study Berbasis Sekolah" (LSBS) by Japan International Cooperation Agency (JICA). SMPN 1 Srandakan has applied lesson study to every subject, in all level, and for all teachers.

Based on the elaboration above, this reasearch is carried out. Problem that should be solved through this research is whether lesson study can improve teachers' competencies of SMPN 1 Srandakan in arraging the materials, method, and media to facilitate their students to learn.

\section{Theoritical Study}

According to Heinich, teacher's competency involves the ability to manage the information and environment so that the students can learn effectivelly. Information means all material that the teachers are going to present in the class and environment means method, media, and equipment. In lesson study, teachers are encouraged to be creative so that they can conduct meaningful lesson for the students. Teachers cooperatively plan the lesson. They discuss about new ideas of material, method, media, and class management. After having a good lesson plan, they choose one of them to be a model to apply the plan. In lesson study, teachers are also required to create new learning experience.

Philosophically, lesson study consists of the study or examination of teaching practice. In lesson study, teachers examine and evaluate their teaching by inviting other teachers to observe their class during the teaching process.

Another definition is taken from the article entitled A Brief Introduction to College Lesson Study.

Lesson study is a simple idea. If you want to improve instruction, what could be more obvious than collaborating with fellow teachers to plan, observe, and reflect on lessons? While it may be a simple idea, lesson study is a complex process, supported by collaborative goal setting, careful data collection on student learning, and protocols that enable productive discussion of difficult issues. ${ }^{1}$

Lesson study refers to a process in which teachers progressively attempt to improve their teaching methods by working with other teachers to examine and critique one another's teaching technique (Baba, 2007, p. 2). Lesson study becomes a model of teachers' training trough effective and incessant discussion based on mutual learning in order to form learning community.

In the article entitled Institute for Lesson Study Research and Application by Dr. Chuck Podhorsky, lesson study is defined as follows:

Lesson study provides one way in which teachers can systematically improve instruction and decrease teacher isolation, if it can be sustained over time. Lesson study provides a process for teachers to collaborate and design lessons while examining successful teaching strategies to increase student learning. ${ }^{2}$

Based on Bill Cerbin (2011), lesson study is the way for teachers to improve the practice of those teachers who participate in it and to build knowledge that can be used by other teachers to improve their practice (p. 3). In addition, lesson study is a system that provides opportunity for the teachers to be professional and progressive. Lesson study is a simple idea to improve instruction with teachers' collaboration in planning, observing, and reflecting the lesson.

\footnotetext{
${ }^{1}$ See http://www.uwlax.edu/sotl/lsp/index2.htm.

2 See http://www.lessonstudy.net/whatislessonstudy.htm.
} 
Applying lesson study means creating an effective teaching and teacher will be different in every meeting. Consequently, students will enjoy the class and get their own experience in learning. Students will always expect the next class because they will get new experience in learning. Lesson study has change teachers' performance on teaching learning process. In other hand, lesson study can improve teacher's competencies.

\section{Research Methodology}

This research is a case study and the subjects are teachers at SMPN 1 Srandakan Yogyakarta, consisting of four English teachers, six science teachers, two social teachers, and five mathematics teachers. Research activities, including planning, implementation, and evaluation, had been held since August until December 2006.

The instruments used are observation sheets, interview guide, and questionnaire.

\section{Lesson Study in SMPN 1 Srandakan}

SMPN 1 Srandakan is one of schools that apply lesson study. On December 2007, SMP Negeri 1 Srandakan was established as one of the pilot schools of "Lesson Study Berbasis Sekolah" (LSBS) by Japan International Cooperation Agency (JICA). SMPN 1 Srandakan has applied lesson study to every subject, in all level, and for all teachers.

SMPN1 Srandakan has 45 teachers with 12 groups of subject matters. Each group has opportunity to open class every Saturday. Firstly, each group of subject plans the lesson. Teachers discuss the material, media, technique, and equipment that are riquired in teaching learning process in the class. In planing the lesson, teacher should answer some questions: What problem the students should work on; what manipulation the students should be provided, how the students will be encouraged to discuss their work, and how to conclude the lesson.

In this planing session, teachers will come with different perspective; some teacher will start with the material point of view; some teachers will explore his or her experience in conducting lesson at the same class, and some will start with media that are required to support the student in learning. Those differenciation will stimulate discussion among teachers. Each teacher has difference experiences and they will maximize the performance.

After deciding the plan, teachers make a quitionaire which contains some questions. The quetionaire will be the guiden for observers in obsserving the lesson. Then, they choose one of them to perform the plan in the class. On Saturday, they are ready to open their class. While observing the class, observers should fill out and answer some questions as follow:

(1) Is there any interaction between students and teacher? And How?

(2) Is there any interaction between student and student?

(3) Can the student learn from the lesson, who and how?

(4) Is there any student who cannot learn from the lesson? Who and why?

(5) Is there any interaction between students and media? How?

The questions can be various. It depends on the teacher who is conducting the lesson.

Having the lesson, the teacher and observers will have a reflection forum. The reflection will be delivered by a moderator. First, the moderator asks the teacher to share his/her feeling during the lesson. Then moderator will invite observer to share their finding during the lesson. During exploration of the finding, a teacher is assigned to 
record all of the discussion in the reflection and gives the record to theteacher who has open the class.

\section{What Can Teacher Learn From Lesson Study?}

Based on the result of interview, it shows that lesson study stimulate teachers at SMPN 1 Srandakan to learn many things, namely;

(1) Teachers learn to work collaboratively;

(2) Teachers learn to analize something;

(3) Teachers learn to design lesson effectively;

(4) Teachers learn to discuss with other teacher;

(5) Teachers learn to be creative in creating meaningful lesson for student;

(6) Teachers learn to think critically in creating lesson plan;

(7) Teachers learn to create interesting activity in teaching learning process;

(8) Teachers learn to share idea;

(9) Teachers learn to give opinion and suggestion;

(10) Teachers learn to be critical.

\section{Conclusion}

Applying lesson study means creating an effective teaching and teachers will be different in every meeting. Consequently, the class will always be interesting and students will always get new experience in learning. Lesson study has change teachers' perception of teaching learning process. In other hand, lesson study can improve teacher's competencies. Lesson study gives chance for teacher to explore their creativities and facilitates teachers to learn.

\section{References}

Baba, T. (2007). Japanese lesson study in mathematics: Its impact, diversity, and potential for educational improvement. Singapore: World Scientific Publishing Co. Pte. Ltd..

Cerbin, B. (2011). Lesson study: Using classroom inquiry to improve teaching learning in higher education. Virginia: Stylus Publishing, LLC.

Cerbin, B., \& Kopp, B. (n.d.). A brief introduction to college lesson study. Retrieved from http://www.uwlax.edu/sotl/1sp/index2.htm

Heinich, R., Molenda, M., Russell, J. D., \& Sharon, S. E. (1996). Instructional media and technology for learning. New Jersey: Prentice-Hall. Inc..

What is lesson study? (n.d.). Retrieved from http://www.tc.columbia.edu/lessonstudy/lessonstudy.html 